Borneo Journal of Social Science \& Humanities

DOI: https://doi.org/10.35370/bjssh.2021.3.1-01

e-ISSN:2682-8235

(C) 2018, UCTS Publisher.

Submitted: 12 August 2020

Accepted: 21 June 2021

Published: 30 June 2021

\title{
A Descriptive Study on Consumer Attitudes Towards Myanmar Cuisine Restaurants in Mandalay
}

\author{
Than Than Win*1, Khin Ohnmar Pa Pa Naing ${ }^{2}$, \\ ${ }^{1}$ Lecturer, Department of Commerce, Yangon University of Economics \\ ${ }^{2}$ Lecturer, Department of Commerce, Yangon University of Economics \\ *Corresponding author: thanthanwin.291@ gmail.com
}

\begin{abstract}
This study aims to investigate the consumer attitudes towards Myanmar Cuisine Restaurants in Mandalay. The purpose of this study is to analyze the relationship between demographic factors and marketing mix as well as to analyze consumer attitudes towards custom issues, social and group issues and marketing mix of Myanmar Cuisine Restaurants in Mandalay. The targeted sample was 130 customers who live in different townships in Mandalay such as Chan Aye Tharzan Township, Aung Myae Tharzan Township, Pyi Gyi Tagon Township, and Amarapura Township. The research methodology is descriptive analysis. The primary data was collected by using simple random sampling method. The analyses revealed that a majority of consumers was satisfied by variety of food offered in menu and cleanliness of restaurants concerning with product items. In addition, they also expressed agreement that they choose Myanmar Cuisine Restaurants that offering good taste and delicious even though the price is expensive. Moreover, they always select the restaurants that it can easily be accessible. In this study, 33 respondents were selected in "Daw Aye Kyin" Myanmar Cuisine Restaurant because of its delicious taste and variety of food in menu.
\end{abstract}

Keywords: Consumer attitudes, Cuisine Restaurants, Marketing mix, Consumers satisfied, Marketing mix, Promotion,

\section{Introduction}

Understanding consumer attitudes will assist a business to better understand their consumer and perhaps even alter their attitudes. Current business environment is in fact fast changing and all organizations are passing through the challenges of such transformation. As the businesses become more consumer-oriented, they need to understand consumer attitudes in purchasing the product or service.

Consumer attitude is a composite of three elements: cognitive information, affective information, and information concerning a consumer's past behavior and future intentions. In other words, attitude consists of thoughts or beliefs, feelings, and behaviors or intentions towards a particular thing, which is usually a good or service. The history of Myanmar Cuisine can best be described as a fusion between Chinese and Indian cuisine with a slight influence from Thai food but is very different from the Thai, Indian, and Chinese food. In addition, it does have its own flavors and techniques. Rice is the most important staple food for Myanmar people rather than other variety of basic foods. Stir-fry and curry dishes make up every day meal. Many interesting meat and seafood dishes, and a variety of exotic vegetable dishes can be found in the cuisine. 
Borneo Journal of Social Science \& Humanities

DOI: https://doi.org/10.35370/bjssh.2021.3.1-01

e-ISSN:2682-8235

(C) 2018, UCTS Publisher.

Submitted: 12 August 2020

Accepted: 21 June 2021

Published: 30 June 2021

Spices and condiments play a vital role in preparing fritters, soups, salads, and main dishes. Soups and salads are usually accompanied the main meal, although course by course can also be quite exciting. The indispensable ingredients consist of fish sauce, shrimp paste, dried shrimps, soy sauce, rice flour, garlic, ginger, lemongrass, turmeric, tamarind, coriander, mint, chilies, and coconut milk.

Traditionally, most of Myanmar people use to take their breakfast, lunch, and dinner at home with their family, relatives, friends, and colleagues. Nowadays, there are many challenges in life to fulfill responsibilities for family, social, occupation, economic, and many others. People give a valuable contribution in their environment regardless of physically and psychologically. As a result, they are putting effort and time in their workplaces, professional field, and careers. At the same time, they get lesser time to meet with their family members at home, and especially having constraint time for cooking. On the other hand, they have been engaged to the widespread habit of eating out together with family members, relatives, friends, classmates, and partners for discussing and meeting about business and etc. Therefore, Myanmar Cuisine Restaurants are not a place merely for eating but also for discussion for business, sharing and gaining information, and meeting places.

When individual's business and income level are improving, they are extending their interests in consumption. As a result, there is certain a huge market opportunity for Myanmar Cuisine Restaurants in Mandalay to persuading people who are busy like bees as well as time strap people for cooking, and people who love Myanmar Cuisine. In sum, this study is to explore consumer attitude that is very important for development of Myanmar Cuisine Restaurants in Mandalay. Based on the above study; the following objectives are:

i. to analyze the relationship between demographic factors and marketing mix towards Myanmar Cuisine Restaurants in Myanmar; and

ii. to describe consumer attitudes towards marketing mix of Myanmar Cuisine Restaurants in Mandalay.

\section{Literature Review}

\section{Consumer Attitude}

The attitude of the customer is composed of three elements: cognitive information, affective information, and information about the past actions and potential intentions of the consumer. In other words, attitude consists of thoughts or beliefs, feelings, and behaviors or intentions towards a particular thing, which is usually a good or service. Simply, attitude is a person's overall evaluation of a concept (Peter \& Olson 1993). These evaluations can be created by both affective and cognitive systems (Fishbein \& Ajzen 1981). A more detailed concept of attitude can be defined as an attitude with regard to some aspect of our environment is an ongoing organization of motivational, emotional, perceptual, and cognitive processes with respect to some aspect of our environment (Alam \& Iqbal 2007). Thus, attitudes are an outcome of psychological mechanism that cannot be clearly observable or measured but can be inferred by what people say or what they do (Alam \& Iqbal 2007). The affective system produces affective responses including emotions, feelings, moods, and evaluations or attitudes. These favorable or unfavorable affective responses 
Borneo Journal of Social Science \& Humanities

DOI: https://doi.org/10.35370/bjssh.2021.3.1-01

e-ISSN:2682-8235

(C) 2018, UCTS Publisher.

Submitted: 12 August 2020

Accepted: 21 June 2021

Published: 30 June 2021

create attitudes as they become associated with a product or brand without conscious, cognitive processing of information about the product or brand (Peter \& Olson 1993).

\section{Marketing mix}

According to Kotler and Armstrong, (2010) has stated the marketing mix consists of all the firm can do to impact the demand for its product (p. 76). According to Chan (1999), it has cited that fast food consumer behavior also related to the marketing mix which includes food types eaten, restaurants, quality in term of clean and hygienic, advertisement, price, and location. Product means the mix of products and services that the company provides to the target market because price has played an important role in helping to achieve the purpose of the company (Kotler \& Armstrong, 2010, p. 76). In the fast food restaurant, the products can be recognized by the customer due to the design, features, brand name, and packaging. For the price, it's the amount of money customers must pay to obtain the product. The price is the sum of values that customers give up in order to profit from having a good or service (Kotler \& Armstrong, 2010, p. 76). The firm can set the price to attract the customers or to remain profitable as retaining existing customers. Applying to the quick service restaurant industry, Thai people are also price sensitive. But, fast food stores in Thailand have higher price when compared to the local food. Thus, this aspect should be included in order to analyze the consumer choice in fast food consumption. According to Kotler and Armstrong, (2010) has cited place that includes company activities making product available to target consumers (p. 76). Also, it is known as channel, distribution, or intermediary. For the fast food industry in Thailand especially in Bangkok, outlets can also be found in store of various large chains. The location of each fast food chain stores are convenient for consumers to visit. In addition, most fast food stores now have delivery service which is a higher degree of convenience for the customer. Activities that convey the merits of the product and convince target buyers to purchase it are intended in marketing program (Kotler \& Armstrong, 2010, p. 76). Consumer promotional tools includes samples, coupons, refunds, premiums, and etc. The marketing of their product will effectively attract Thai consumers because most fast food restaurants have opened in Thailand. The promotion of fast foods in Thailand is based on discount coupons which are the certificate giving buyers a saving when they purchased specified product since coupon can promote and stimulate sales of a mature brand (Kotler \& Armstrong, 2010, p. 503).

\section{Scope and Method of the Study}

This study concentrated on the consumer attitudes towards Myanmar Cuisine Restaurants in Mandalay. The primary data was collected from 130 respondents by applying descriptive method on the demographic factors such as age, gender, marital status, income level, education and occupation. The survey method was conducted by distributing structured questionnaires (FivePoint Likert Scale) to the respondents from various townships in Mandalay such as Chan Aye Tharzan Township, Aung Myae Tharzan Township, Pyi Gyi Tagon Township and Amarapura Township. To know consumer attitudes in detail, custom issues, social and group issues, marketing mix (product and service, price, place and promotion) were analyzed. The self-administered questionnaires have been developed for the data collection. The secondary data conducted from relevant journals, documents, reference books and internet. 
Borneo Journal of Social Science \& Humanities

DOI: https://doi.org/10.35370/bjssh.2021.3.1-01

e-ISSN:2682-8235

(C) 2018, UCTS Publisher.

Submitted: 12 August 2020

Accepted: 21 June 2021

Published: 30 June 2021

\section{Analysis and Findings}

\section{Research Design}

The survey method was conducted through Descriptive method. To know consumer attitudes in details, custom issues, social and group issues, marketing mix (product and service, price, place and promotion) were analyzed. The self-administered questionnaires have been developed for the data collection. In this section, total numbers of 130 respondents were taken from Chan Aye Tharzan Township, Aung Myae Tharzan Township, Pyi Gyi Tagon Township, and Amarapura Township, and they use to have lunch/dinner at Too Too, Daw Lay May, Aye Myit Tar, Magalarbar and Daw Aye Kyin. Then, they were surveyed by distributing structured questionnaires. The FivePoint Likert Scale was used to measure consumer attitudes towards Myanmar Cuisine Restaurants. Descriptive Statistics such as frequency, percentage, and mean value were used in this study.

Table 1: Demographic Characteristics of Respondents

\begin{tabular}{|l|c|c|}
\hline Gender & No of Respondents & Percentage \\
\hline Male & 63 & 48 \\
\hline Female & 67 & 52 \\
\hline Total & 130 & 100 \\
\hline Age & No of Respondents & Percentage \\
\hline Under 20 years & 10 & 8 \\
\hline Between 21 and 30 years & 30 & 23 \\
\hline Between 31 and 40 years & 24 & 18 \\
\hline Between 41 and 50 years & 15 & 12 \\
\hline Over 50 years & 130 & 100 \\
\hline Total & 5 & Percentage \\
\hline Education & 16 & 4 \\
\hline High School & 84 & 12 \\
\hline University Students & 19 & 65 \\
\hline Graduate & 6 & 15 \\
\hline Post Graduate & 130 & 5 \\
\hline Others & 12 & 100 \\
\hline Total & 9 & Percentage \\
\hline Occupation & 60 & 9 \\
\hline Students & 25 & 7 \\
\hline Dependent & 24 & 46 \\
\hline Private Staff & 130 & 19 \\
\hline Government Staff & No of Respondents & 18 \\
\hline Own Business & 17 & Percentage \\
\hline Total & & 13 \\
\hline Income & Nof Respondents & \\
\hline Under 100,000 Kyats & 512 & \\
\hline
\end{tabular}


Borneo Journal of Social Science \& Humanities

DOI: https://doi.org/10.35370/bjssh.2021.3.1-01

e-ISSN:2682-8235

(C) 2018, UCTS Publisher.

Submitted: 12 August 2020

Accepted: 21 June 2021

Published: 30 June 2021

\begin{tabular}{|l|c|c|}
\hline Between 100,000 and 200,000 Kyats & 13 & 10 \\
\hline Between 200,000 and 300,000 Kyats & 52 & 40 \\
\hline Between 300,000 and 400,000 Kyats & 27 & 21 \\
\hline Over 400,000 Kyats & 21 & 16 \\
\hline Total & 130 & 100 \\
\hline
\end{tabular}

Source: Author 2020

According to the contribution percentage shown in Table 1, male contributes $48 \%$ and female contributes $52 \%$ in total number of respondents. The proportion of gender distribution among respondents is not greatly dispersed. The largest proportion of age group is between 21 and 30 years. It takes $39 \%$ in total contribution. The 51 of 130 respondents are from this group. The second highest group is in the 31 to 40 age range. The group contributes $23 \%$. The third largest group is between 41 and 50 years and its contribution is $18 \%$ in total. The smallest amount of respondent are under 20 years and over 50 years which representing $8 \%$ and $12 \%$ respectively.

Accordingly, it is found the respondents comprise different education levels i.e. the graduate takes the largest contribution to this survey relatively to other groups. There are 84 respondents and it also allocates $65 \%$ share. But high school, others, university students, and the post graduate level are getting very low percentage which are 4\%, 5\%,12\% and $15 \%$ respectively.

From point of view of occupation, the biggest share of occupation is private staff i.e. $46 \%$ and total respondents consist of 60 out of total respondents as shown in Table 2. The respondents who involve government staffs are the second contribution group which partaking of $19 \%$ or 25 respondents out of 130. The respondents who are dependent, student, and own businesses are the lowest share of occupation.

The involvement of respondents who have income level between 200,000 Kyats and 300,000 Kyats is the majority. There are 52 respondents out of 130 and made up of $40 \%$ in total. It follows by the group of respondents who have income level between 300,000 Kyats and 400,000 Kyats which consists of $21 \%$ share and 27 respondents. Minority group has income range between 100,000 Kyats and 200,000 Kyats with $10 \%$ share.

Table 2 depicts the mean values between types of occupation and product and service. There are three highest mean value under the occupation of business owners whereby the statements of "availability of variety of food in menu to select" has mean of 4.17, follows by "served by variety of side dishes" with value of 4.04, and "hospitality and friendly attitude of staffs like family members" with mean of 4.17 . 
Borneo Journal of Social Science \& Humanities

DOI: https://doi.org/10.35370/bjssh.2021.3.1-01

e-ISSN:2682-8235

(C) 2018, UCTS Publisher.

Submitted: 12 August 2020

Accepted: 21 June 2021

Published: 30 June 2021

Table 2: Relationship between Occupation and Product (Service)

\begin{tabular}{|l|l|l|l|l|l|l|l|}
\hline & $\begin{array}{l}\text { Availability } \\
\text { of variety } \\
\text { of foods in } \\
\text { menu to } \\
\text { select }\end{array}$ & $\begin{array}{l}\text { Served } \\
\text { by } \\
\text { variety } \\
\text { of side } \\
\text { dishes }\end{array}$ & $\begin{array}{l}\text { Hospitality } \\
\text { and } \\
\text { friendly } \\
\text { attitude of } \\
\text { staffs like } \\
\text { family } \\
\text { members }\end{array}$ & $\begin{array}{l}\text { Cooking } \\
\text { with } \\
\text { healthy } \\
\text { oil, meat, } \\
\text { fish and } \\
\text { vegetables }\end{array}$ & $\begin{array}{l}\text { Quickly } \\
\text { and } \\
\text { effectively } \\
\text { delivery } \\
\text { service }\end{array}$ & $\begin{array}{l}\text { Cleanliness } \\
\text { of Restaurants }\end{array}$ & $\begin{array}{l}\text { Total } \\
\text { Mean } \\
\text { Value }\end{array}$ \\
\hline Students & 3.67 & 3.08 & 3.58 & 3.33 & 3.17 & 3.92 & 3.46 \\
\hline Dependent & 3.89 & 3.78 & 3.22 & 3.11 & 3.44 & 3.89 & 3.56 \\
\hline Private Staff & 3.88 & 3.60 & 3.73 & 3.60 & 3.55 & 3.92 & 3.71 \\
\hline $\begin{array}{l}\text { Government } \\
\text { Staff }\end{array}$ & 3.80 & 3.60 & 3.76 & 3.48 & 3.40 & 3.96 & 3.67 \\
\hline $\begin{array}{l}\text { Own } \\
\text { Business }\end{array}$ & 4.17 & 4.04 & 4.17 & 3.79 & 3.71 & 3.96 & 3.97 \\
\hline
\end{tabular}

Source: Author 2020

Table 3: Relationship between Occupation and price

\begin{tabular}{|l|l|l|l|l|}
\hline Occupation & $\begin{array}{l}\text { Firstly attend to } \\
\text { price when to } \\
\text { choose }\end{array}$ & $\begin{array}{l}\text { Always choose } \\
\text { reasonable price } \\
\text { restaurants }\end{array}$ & $\begin{array}{l}\text { Although price is } \\
\text { expensive, choose } \\
\text { for delicious }\end{array}$ & $\begin{array}{l}\text { Total Mean } \\
\text { Value }\end{array}$ \\
\hline Students & 3.67 & 3.92 & 3.58 & 3.72 \\
\hline Dependent & 3.00 & 3.11 & 3.89 & 3.33 \\
\hline Private Staff & 3.13 & 3.52 & 3.67 & 3.44 \\
\hline Government Staff & 3.40 & 3.76 & 3.80 & 3.65 \\
\hline Own Business & 3.04 & 3.46 & 3.83 & 3.44 \\
\hline
\end{tabular}

Source: Author 2020

As the result of occupation and price, the largest mean value is 3.92 as referring to the statement of "always choose reasonable price restaurants" by students, while the smallest mean values are 3.00 and 3.04 to "firstly attend to price when to choose" by dependent group and business group owners.

Table 4: Relationship between Occupation and Place

\begin{tabular}{|l|l|l|l|l|l|}
\hline Occupation & $\begin{array}{l}\text { Wide space } \\
\text { of } \\
\text { restaurants }\end{array}$ & $\begin{array}{l}\text { Easily } \\
\text { accessible } \\
\text { to reach }\end{array}$ & $\begin{array}{l}\text { Good interior } \\
\text { design and } \\
\text { decoration of } \\
\text { restaurants }\end{array}$ & $\begin{array}{l}\text { Wide space for parking } \\
\text { car pacility }\end{array}$ & $\begin{array}{l}\text { Total } \\
\text { Mean } \\
\text { Value }\end{array}$ \\
\hline Students & 2.92 & 3.67 & 3.25 & 3.08 & 3.23 \\
\hline Dependent & 3.00 & 3.56 & 3.22 & 2.89 & 3.17 \\
\hline Private Staff & 3.37 & 3.55 & 315 & 3.13 & 3.30 \\
\hline
\end{tabular}


Borneo Journal of Social Science \& Humanities

DOI: https://doi.org/10.35370/bjssh.2021.3.1-01

e-ISSN:2682-8235

(C) 2018, UCTS Publisher.

Submitted: 12 August 2020 Accepted: 21 June 2021

Published: 30 June 2021

\begin{tabular}{|l|l|l|l|l|l|}
\hline Government Staff & 3.52 & 3.72 & 3.36 & 3.40 & 3.50 \\
\hline Own Business & 3.67 & 3.92 & 3.63 & 3.54 & 3.69 \\
\hline
\end{tabular}

Source: Author 2020

With regard to Table 4, occupation and place data analysis, the mean value of own business group 3.92 is the largest to the factor "easily accessible to reach" while the smallest mean value 2.89 of dependent group to "wide space for car parking facility".

Table 5: Relationship between Occupation and Promotion

\begin{tabular}{|l|l|l|l|l|}
\hline Occupation & $\begin{array}{l}\text { Advertisement in } \\
\text { newspapers and } \\
\text { journals }\end{array}$ & $\begin{array}{l}\text { Distributing by Privilege action } \\
\text { pamphlets and } \\
\text { flyers }\end{array}$ & $\begin{array}{l}\text { Total } \\
\text { to regular } \\
\text { customers }\end{array}$ & $\begin{array}{l}\text { Mean } \\
\text { Value }\end{array}$ \\
\hline Students & 2.75 & 2.50 & 2.92 & 2.72 \\
\hline Dependent & 2.22 & 2.22 & 2.56 & 2.33 \\
\hline Private Staff & 2.50 & 2.37 & 2.72 & 2.53 \\
\hline Government Staff & 2.64 & 2.56 & 2.62 & 2.63 \\
\hline Own Business & 2.54 & 2.67 & 2.88 & 2.69 \\
\hline
\end{tabular}

Source: Author 2020

According to Table 5, it has been found that there is no mean value over 3.00 from five groups. It can say that it is the highest value 2.92 by student group to "privilege action to regular customers".

\section{Relationship between Income Level and Marketing Mix}

It has been examined the relationship between income level and marketing mix by five level of income such as under 100,00 Kyat, between 100,000 and 200,000 Kyats, between 200,000 and 300,000 Kyats, between 300,000 and 400,000 Kyats and over 400,000 Kyats.

Table 6: Relationship between Income Level and Product (Service)

\begin{tabular}{|l|l|l|l|l|l|l|l|}
\hline & $\begin{array}{l}\text { Availability } \\
\text { of variety } \\
\text { of foods in } \\
\text { menu to } \\
\text { select }\end{array}$ & $\begin{array}{l}\text { Served } \\
\text { by } \\
\text { variety } \\
\text { of side } \\
\text { dishes }\end{array}$ & $\begin{array}{l}\text { Hospitality } \\
\text { and } \\
\text { friendly } \\
\text { attitude of } \\
\text { staff like } \\
\text { family } \\
\text { members }\end{array}$ & $\begin{array}{l}\text { Cooking } \\
\text { with } \\
\text { healthy } \\
\text { oil, meat, } \\
\text { fish and } \\
\text { vegetables }\end{array}$ & $\begin{array}{l}\text { Quickly } \\
\text { and } \\
\text { effectivel } \\
\text { y delivery } \\
\text { service }\end{array}$ & $\begin{array}{l}\text { Cleanliness } \\
\text { of } \\
\text { Restaurants }\end{array}$ & $\begin{array}{l}\text { Total } \\
\text { Mean } \\
\text { Value }\end{array}$ \\
\hline $\begin{array}{l}\text { Under } \\
100,000\end{array}$ & 3.18 & 2.94 & 2.71 & 2.53 & 2.82 & 3.24 & 2.90 \\
\hline $\begin{array}{l}\text { Between } \\
100,000 \text { and } \\
200,000\end{array}$ & 3.00 & 2.62 & 2.62 & 2.46 & 2.38 & 3.00 & 2.68 \\
\hline
\end{tabular}


Borneo Journal of Social Science \& Humanities

DOI: https://doi.org/10.35370/bjssh.2021.3.1-01

e-ISSN:2682-8235

(C) 2018, UCTS Publisher.

Submitted: 12 August 2020

Accepted: 21 June 2021

Published: 30 June 2021

\begin{tabular}{|l|l|l|l|l|l|l|l|}
\hline $\begin{array}{l}\text { Between } \\
200,000 \text { and } \\
300,000\end{array}$ & 3.69 & 3.46 & 3.62 & 3.71 & 3.56 & 3.94 & 3.66 \\
\hline $\begin{array}{l}\text { Between } \\
\begin{array}{l}300,000 \text { and } \\
400,000\end{array}\end{array}$ & 4.11 & 4.00 & 4.30 & 3.63 & 3.59 & 3.81 & 3.91 \\
\hline $\begin{array}{l}\text { Over } \\
400,000\end{array}$ & 4.14 & 3.86 & 4.00 & 3.52 & 3.67 & 4.10 & 3.88 \\
\hline
\end{tabular}

Source: Author 2020

According to Table 6, the first largest mean values are 4.30 of income level between 300,000 and 400,000 Kyats group to "hospitality and friendly attitude of staffs like family members". As second largest mean value 4.14 of over 400,000 Kyats to "availability of variety of foods in menu to select" as well as followed by 4.11 of respondents who get income level between 300,000 and 400,000 Kyats to this factor. Then 4.10 mean value of group of over 400,000 Kyats to "cleanliness of restaurants" is the fourth largest value in relationship between income and product. The smallest mean value is 2.38 to "quickly and effectively delivery services" by the respondents who get income level between 100,000 and 200,000 Kyats per month.

Table 7: Relationship between Income Level and Price

\begin{tabular}{|l|l|l|l|l|}
\hline Income (Kyats) & $\begin{array}{l}\text { Firstly attend to } \\
\text { price when to } \\
\text { choose }\end{array}$ & $\begin{array}{l}\text { Always choose } \\
\text { reasonable price } \\
\text { restaurants }\end{array}$ & $\begin{array}{l}\text { Although price is } \\
\text { expensive, choose } \\
\text { for delicious }\end{array}$ & $\begin{array}{l}\text { Total Mean } \\
\text { Value }\end{array}$ \\
\hline Under 100,000 & 2.76 & 2.88 & 3.06 & 2.90 \\
\hline $\begin{array}{l}\text { Between 100,000 } \\
\text { and 200,000 }\end{array}$ & 2.77 & 3.00 & 2.62 & 2.79 \\
\hline $\begin{array}{l}\text { Between 200,000 } \\
\text { and 300,000 }\end{array}$ & 3.12 & 3.56 & 3.69 & 3.46 \\
\hline $\begin{array}{l}\text { Between 300,000 } \\
\text { and 400,000 }\end{array}$ & 3.41 & 3.63 & 3.70 & 3.58 \\
\hline Over 400,000 & 2.95 & 3.33 & 4.05 & 3.44 \\
\hline
\end{tabular}

Source: Author 2020

Based on survey data in Table 7, the mean value 4.05 is the largest by group of respondents who get income over 400,000 Kyats per month to the factor "although price is expensive, chose for delicious". The second largest value is 3.70 for income level between 300,000 and 400,000 Kyats as referring to the statement of "although price is expensive, choose for delicious". The smallest mean value is 2.26 which indicates to the statement of "although price is expensive, choose for delicious" by group of between 100,000 Kyats and 200,000 Kyats. 
Borneo Journal of Social Science \& Humanities

DOI: https://doi.org/10.35370/bjssh.2021.3.1-01

e-ISSN:2682-8235

(C) 2018, UCTS Publisher.

Submitted: 12 August 2020

Accepted: 21 June 2021

Published: 30 June 2021

Table 8: Relationship between Income Level and Place

\begin{tabular}{|l|l|l|l|l|l|}
\hline Income (Kyats) & $\begin{array}{l}\text { Wide } \\
\text { space of } \\
\text { restaurants }\end{array}$ & $\begin{array}{l}\text { Easily } \\
\text { accessible } \\
\text { to reach }\end{array}$ & $\begin{array}{l}\text { Good interior design } \\
\text { and decoration of } \\
\text { restaurants }\end{array}$ & $\begin{array}{l}\text { Wide space for } \\
\text { car parking } \\
\text { facility }\end{array}$ & $\begin{array}{l}\text { Total } \\
\text { Mean } \\
\text { Value }\end{array}$ \\
\hline Under 100,000 & 2.35 & 2.82 & 2.76 & 2.65 & 2.65 \\
\hline $\begin{array}{l}\text { Between 100,000 } \\
\text { and 200,000 }\end{array}$ & 2.77 & 2.92 & 2.62 & 2.46 & 2.69 \\
\hline $\begin{array}{l}\text { Between 200,000 } \\
\text { and 300,000 }\end{array}$ & 3.21 & 3.67 & 3.17 & 3.12 & 3.29 \\
\hline $\begin{array}{l}\text { Between 300,000 } \\
\text { and 400,000 }\end{array}$ & 3.48 & 3.52 & 3.44 & 3.19 & 3.41 \\
\hline Over 400,000 & 3.86 & 3.76 & 3.38 & 3.71 & 3.68 \\
\hline
\end{tabular}

Source: Author 2020

According to Table 8, the mean value 3.86 is the largest value contributed by group of income over 400,000 Kyats as referring to the statement "wide space of restaurants". The second largest value is 3.67 by group of respondents between 200,000 and 300,000 Kyats, denoting to the statement of "easily accessible to reach". The mean value 2.35 is the lowest score in this table.

Table 9: Relationship between Income Level and Promotion

\begin{tabular}{|l|l|l|l|l|}
\hline Income (Kyats) & $\begin{array}{l}\text { Advertisement in } \\
\text { newspapers and } \\
\text { journals }\end{array}$ & $\begin{array}{l}\text { Distributing by } \\
\text { pamphlets and } \\
\text { flyers }\end{array}$ & $\begin{array}{l}\text { Privilege action } \\
\text { to regular } \\
\text { customers }\end{array}$ & Total Mean Value \\
\hline Under 100,000 & 2.00 & 2.00 & 2.35 & 2.12 \\
\hline $\begin{array}{l}\text { Between 100,000 } \\
\text { and 200,000 }\end{array}$ & 2.08 & 2.00 & 2.23 & 2.10 \\
\hline $\begin{array}{l}\text { Between 200,000 } \\
\text { and 300,000 }\end{array}$ & 2.56 & 2.46 & 2.71 & 2.58 \\
\hline $\begin{array}{l}\text { Between 300,000 } \\
\text { and 400,000 }\end{array}$ & 2.81 & 2.74 & 2.85 & 2.80 \\
\hline Over 400,000 & 2.38 & 2.29 & 2.57 & 2.41 \\
\hline
\end{tabular}

Source: Author 2020

Like the relationship between other demographic factors and promotion, there is no mean value over 3.00 while the largest mean value is 2.85 and the smallest mean value is 2.00 . As overall mean value, all income groups expressed disagree statement on all items of promotion.

\section{Consumer Attitudes towards Marketing Mix}

With regard to the data about product and service shown in Table 13, it is found that the mean values of "cleanliness of restaurants" is the largest mean value 3.93 and the second largest value of "availability of variety of foods in menu to select" is 3.90 . The mean value of "hospitality and 
Borneo Journal of Social Science \& Humanities

DOI: https://doi.org/10.35370/bjssh.2021.3.1-01

e-ISSN:2682-8235

(C) 2018, UCTS Publisher.

Submitted: 12 August 2020

Accepted: 21 June 2021

Published: 30 June 2021

friendly attitude of staffs like family members" is the third largest 3.77 and followed by the mean value of "served by variety of side dishes" is 3.65 and then the mean value of "cooking with healthy oil, meat, fish and vegetable" is 3.55. The smallest mean value is 3.15 to factor, "quickly and effectively delivery service".

Table 10: Consumer Attitudes towards Product and Service

\begin{tabular}{|l|l|}
\hline Products and Services & Mean Value \\
\hline Availability of variety of foods in menu to select & 3.9 \\
\hline Served by variety of side dishes & 3.65 \\
\hline Hospitality and friendly attitude of staffs like family members & 3.77 \\
\hline Cooking with healthy oil, meat, fish and vegetables & 3.55 \\
\hline Quickly and effectively delivery services & 3.51 \\
\hline Cleanliness of restaurants & 3.93 \\
\hline Overall Mean & 3.72 \\
\hline
\end{tabular}

Source: Author 2020

Table 11: Consumer Attitudes towards Price

\begin{tabular}{|l|l|}
\hline Price & Mean Value \\
\hline Firstly consider about price when to choose & 3.21 \\
\hline Always choose reasonable price restaurants & 3.56 \\
\hline Although price is expensive, choose for delicious & 3.73 \\
\hline Overall Mean & 3.50 \\
\hline
\end{tabular}

Source: Author 2020

Concerning with the survey data, the mean value 3.73 is the largest score in this table and next largest value is 3.56. In addition they do not consider about price when to choose Myanmar Cuisine Restaurants because the data mean value is 3.21 .

Table 12: Consumer Attitudes towards Place

\begin{tabular}{|l|l|}
\hline Place & Mean Value \\
\hline Wide space of restaurants & 3.38 \\
\hline Easily accessible to reach & 3.66 \\
\hline Good interior design and decoration of restaurants & 3.29 \\
\hline Wide space for car parking facility & 3.24 \\
\hline Overall Mean & 3.39 \\
\hline
\end{tabular}

Source: Author 2020

As of survey data, it is found that the mean value 3.66 for "easily accessible to reach" is the largest value while other statements have been expressed as the mean value 3.38 for "wide space of restaurants", the mean value 3.29 for "good interior design and decoration of restaurants", the mean value 3.24 for "wide space for car parking facility". By mean of overview to place, it is shown that the mean value is 3.39 . 
Borneo Journal of Social Science \& Humanities

DOI: https://doi.org/10.35370/bjssh.2021.3.1-01

e-ISSN:2682-8235

(C) 2018, UCTS Publisher.

Submitted: 12 August 2020

Accepted: 21 June 2021

Published: 30 June 2021

Table 13: Consumer Attitudes towards Promotion

\begin{tabular}{|l|l|}
\hline Promotion & Mean Value \\
\hline Advertisement in newspapers and journals & 2.54 \\
\hline Distributing by pamphlets and flyers & 2.46 \\
\hline Privilege action to regular customers & 2.75 \\
\hline Overall Mean & 2.58 \\
\hline
\end{tabular}

Source: Author 2020

According to Table 13, the respondents have described the mean value 2.75, the item of "privilege action to regular customers", and the mean value 2.54 for "advertisement in newspaper and journals" and the least value is 2.46 of "distributing by pamphlets and flyers".

\section{Finding and Suggestions}

This research study explores consumer attitudes towards Myanmar Cuisine Restaurants in Mandalay. The questionnaire survey was conducted with 63 male and 67 female who use to eat Myanmar Cuisine at restaurants. There are many Myanmar Cuisine Restaurants in Mandalay by meant of popular and successful restaurants such as Too Too, Daw Lay May, Aye Myit Tar, and Daw Aye Kyin, as well as newly open Myanmar Cuisine Restaurants as Mingalarbar and Daung Lan Gyi. This analysis is providing critical consumer attitudes and their in depth information about Myanmar Cuisine Restaurants. This chapter is organized with findings, suggestions, and need for further study. To sum up, this research has provided a depth analysis of the proposed framework that focusing on demographic of Mandalay consumer towards Myanmar Cuisine Restaurants as well as consumer attitudes towards marketing mix elements. Interestingly, demographic variables namely education level, occupation, and income level are provided for analyzing the relationship towards marketing mix. Moreover, the attitudes of Mandalay consumer towards price, place, promotion, and distribution channel are also taken into consideration.

According to the relationship between education, occupation, income, product and service, high school and post graduate level made a remarkable agreement on six factors of product and service. From the perspective of occupation, it has been described that business owner group also agrees with all factors of product and service, and especially the whole occupation categories showed favorable condition on cleanliness of restaurants. As for income analysis data, income level between 300,000 and 400,000 Kyats and over 400,000 Kyats per month appointed that they agree on availability of variety of foods in menu to select, served by variety of side dishes, hospitality and friendly attitude of staffs like family members and cleanliness of restaurants. In studying of income level between 200,000 and 300,000 Kyats, they have more favorable restaurants by cooking with healthy ingredients (oil, meat, fish, and vegetables), as well quickly and effectively delivery service.

According to the relationship between education, occupation, and income and price, the price is not important when to choose Myanmar Cuisine Restaurants. Education level of high school, post graduate and other, occupation categories of dependent, government staff and own business, and income level over 400,000 Kyats per month always select good taste and delicious Myanmar Cuisine Restaurants even the price is expensive. 
Borneo Journal of Social Science \& Humanities

DOI: https://doi.org/10.35370/bjssh.2021.3.1-01

e-ISSN:2682-8235

(C) 2018, UCTS Publisher.

Submitted: 12 August 2020

Accepted: 21 June 2021

Published: 30 June 2021

According to the relationship between education, occupation, and income and place, high school, university student and post graduate group, own business respondents and income level over 400,000 Kyats per month have positive attitudes on restaurants that are located in easily accessible to reach.

In the study, there is only one negatively impact marketing mix to respondents that is promotion because most of respondents answered that they did not go to Myanmar Cuisine Restaurants due to advertising in journal and magazines, distributing pamphlets, and flyers and finally offering privilege action to regular customers.

In can be found that "Daw Aye Kyin" was chosen as the most select Myanmar Cuisine Restaurants relatively to Too Too, Daw Lay May, Aye Myit Tar, and Mingalarbar. Secondly they selected as the most Aye Myit Tar and thirdly selected Too Too restaurant. The respondents usually go to restaurants as usual when compare to others. They are frequently going to Myanmar Cuisine Restaurants at least five times within one month.

By mean of data related with social and group issues, consumer attitudes towards Myanmar Cuisine Restaurants has been expressed that the consumers are visiting to Myanmar Cuisine Restaurants with friends and classmates more than with family members. But the consumer attitude is natural status upon going to restaurants with recommendation of fiends and neighborhoods.

It has been concluded that the respondents are satisfied to be offered by availability of variety of foods in menu to select, cleanliness of restaurants, and hospitality and friendly attitude of staffs. As overall about the price, it has not been considered when to choose restaurants.

Generally among marketing mix (Product and Service, Price, Place and Promotion), the factors in product and service are higher favorable for consumers the core reason to go to Myanmar Cuisine Restaurants compared to price, place and promotion.

As discovered in the survey of consumer attitudes towards Myanmar Cuisine Restaurants, there are some suggestion points relating to demographic variable towards marketing mix factors based on respondents attitude in Mandalay.

Thus, Myanmar Cuisine Restaurants in Mandalay should be more concerned on product and service issues most of respondents expressed agree on these factors. The can maintain variety of food to choose in menu as well as to create new menu items with fully Myanmar traditional taste. Moreover offering variety of side dishes play in important role of Myanmar Cuisine and therefore the restaurants should consider the role of side dishes to maintain regular customers. In term of survey data, the restaurants can express their customers they are always paying attention to cleanliness of restaurants as an important factor. The restaurants' owners should frequently arrange employees training to fulfill the customer's needs and wants. Without no doubt the best services and beyond the expectation of customers will generate invaluable profitability and growth.

When the restaurants offer good taste and delicious, the respondents do not consider the price. So taste is very important for Myanmar Cuisine Restaurants to keep not only regular customers but also to persuade new customers. Due to the majority of respondents have favorable attitude towards easily accessible to reach, the restaurant's location should be considered when attracting the customers. Lastly, promotion activities could be failed to get new customers because all of respondents answered promotion items as neither agree nor disagree. 
Borneo Journal of Social Science \& Humanities

DOI: https://doi.org/10.35370/bjssh.2021.3.1-01

e-ISSN:2682-8235

(C) 2018, UCTS Publisher.

Submitted: 12 August 2020

Accepted: 21 June 2021

Published: 30 June 2021

\section{Need for Further Study}

Although this study was a first important step into the exploration of Myanmar Cuisine Restaurants and consumer attitudes, there are many factors to continue further study about consumer attitudes towards Myanmar Cuisine restaurants in Mandalay. Because in this study the respondents were from only four townships as Chan Aye Tharzan Township, Aung Myae Tharzan Township, Pyi Gyi Tagon Township and Amarapura Township. In Mandalay, there are total seven townships and therefore other townships would be added in survey for more complete information from consumers. At the same time, the more respondents are collected in the research, the more the strongest results are given in the study. To know consumer attitudes towards Myanmar Cuisine Restaurants in Mandalay, it needs to further study such as consumer behavior, consumer buying decisions and consumer perception. Especially in the survey data, only five popular and successful Myanmar Cuisine Restaurants in Mandalay were counted to examine consumer attitudes.

\section{References}

Alam, S. M. I. \& Iqbal, M. M. (2007). Consumer attitude toward new products in Dhaka City: A case study of two products. Daffodil International Journal of Business and Economics, 2(1), 1-19.

Chan, T. S. (1999). Consumer behavior in Asia. New York: The Haworth Press.

Fishbein, M. \& Ajzen, I. (1981). Attitudes and voting behavior: An application of the theory of reasoned action. Progress in Applied Social Psychology, 1, 253-313.

Kotler, P. T. \& Armstrong, G. (2010). Principles of Marketing. Prentice Hall.

Nuzakkeerul, H. M. \& Tamima, H (2009). Consumer Attitudes towards Restaurants in Dhaka City. ASA University Review, 3(2).

Pattaraporn, J., \& Chitraporn, Y. (2011). Consumer attitudes toward Quick Service Restaurants in Thailand. Master Thesis, Malardalen University Sweden.

Peter, J. P. \& Olson, J. C. (1993). Consumer behavior and marketing strategy. Third Edition, Irwin, Boston.

Schiffman, L. G. \& Kanuk, L. L. (2004). Consumer Behavior. Eighth Edition, Person International. 